\title{
APRESENTAÇÃO \\ CULTURA LITERÁRIA NA AMÉRICA LATINA
}

Claudia Lorena Fonseca

(Organizadora)

Encontros são possibilidades, múltiplas possibilidades que, a modo de síntese, poderiam ser traduzidas por possibilidade de transcendência. Buscamo-nos, nos encontramos e construímos espaços, conhecimento, vínculos: experiência. Encontros são oportunidades de ver, saber e sentir o outro, ir além dos muros acadêmicos e de nossas práticas cotidianas. Compartilhar e nos vermos no olhar e através do olhar do outro. E a alegria de ver criados novos vínculos acadêmicos e afetivos, e renovados os já existentes, fortalecendo nossas redes.

A edição da Revista Caderno de Letras que ora apresentamos se configura como fruto da experiência do encontro. Tem sua origem na produção de grupos com os quais compartilhamos nossos caminhos e contempla a produção de investigadores brasileiros, argentinos e mexicanos. Um olhar sobre o conjunto de artigos nos permite conhecer um pouco mais sobre o que se está produzindo em nossos Programas de pós-graduação, em seus diversos níveis, no âmbito da América Latina, referente ao tema que unifica nosso trabalho de investigação. Esta edição conta com um conjunto de artigos que tratam de questões que vão do ensaio à tradução, passando pela literatura brasileira e hispano-americana, sendo que, curiosamente, a literatura argentina aparece como tema de estudos brasileiros, ao mesmo tempo em que estudos argentinos tratam da literatura irlandesa. Questões relativas ao discurso, interdiscursividade, história e memória permeiam também os estudos compilados nesta edição.

Assim, começamos a leitura com o artigo de Claudio Maíz, o qual propõe algumas formas de leitura densa da cultura literária, especialmente do ensaio, bem como um mapeamento tentativo da ensaística argentina dos séculos XX e XXI, a partir do que teoricamente propõe. Na sequência, vida e obra da escritora chilena María Luisa Bombal, e seus vínculos com a revista argentina Sur, ensejam a reflexão de Andrea Kahmann sobre as condicionantes para o estabelecimento (e/ou exclusão) de um autor no 
cânone. Já Tiago Pedruzzi compara duas traduções brasileiras de Martin Fierro, de José Hernandéz, obra indiscutivelmente canônica que, incompreensivelmente, apenas cem anos depois de sua primeira edição é traduzida para o português. Ainda neste primeiro bloco, estabelecemos contato com a literatura andina pelos olhos mexicanos de Raúl López Espinosa, a partir da crítica a estudos prévios sobre a obra do peruano Juan de Espinosa Medrano, mais especificamente sobre a tensão que se estabelece entre as formas de abordagem que se fazem a respeito da cultura andina.

A obra de Walter Benjamin e suas teses sobre a história é tema dos estudos de Claudio Cruz e de José Mariano do Carmo. Cruz trata do conceito de imagem dialética, desenvolvido por Benjamin no Liuro das passagens, enquanto Mariano trata dos conceitos de memória, recordação, progresso e barbárie. Memória, luto e melancolia na obra de Bernardo Kucinski, e sua relação com os desaparecimentos políticos durante a ditadura militar no Brasil são o fio condutor do trabalho que apresentamos com Cristina Napp dos Santos, enquanto a obra do chileno Roberto Bolaño é objeto de investigação de Talita Jordina dos Santos. Na sequência, as relações que se estabelecem entre literatura e fotografia, em Julio Cortázar, e entre literatura e cinema, em Paulo Lins são abordadas por Michele Savaris e Eliane Dutra, respectivamente.

De La Pampa argentina nos chegam três estudos, os quais se debruçam sobre a literatura irlandesa a partir de uma perspectiva calcada na tradução como diálogo intercultural. Memória e identidade são temas recorrentes nos estudos de Griselda Gugliara, Melina Vigari e Isabel Arriaga. E, por fim, a literatura brasileira se faz presente de forma mais marcada, a partir de quatro estudos, diversos em suas abordagens: seja o foco no discurso manipulador do narrador, no artigo que apresentamos com Eugenia Basso ou nas questões relativas à obra poética de Manoel de Barros, de autoria de Maria Fernanda Carvalho; seja na discussão que tem por tema os positivismos no Brasil na virada do século XIX para o XX, que é a proposta de Isabela Melim Borges, ou ainda nas performances de sujeito-mulher nos contos de Altair Martins, objeto de estudo de Luana Kruger, que reflete sobre a idealização da maternidade na sociedade contemporânea. Esperamos que disfrutem desse encontro. 